\title{
EFFECT OF INDUSTRIAL SLUDGE ON CONCENTRATION AND DISTRIBUTION PATTERN OF LEAD, CADMIUM AND NICKEL IN ROOT, STEM AND LEAF OF RED AMARANTH (AMARANTHUS GANGETICUS L.) IN SILTY CLAY LOAM SOIL
}

\author{
M.A. RAUF ${ }^{1}$, P. PARKPIAN ${ }^{2}$ AND M.T.I. MIAH ${ }^{3}$ \\ ${ }^{1}$ Soil Resources Development Institute, Regional laboratory, Farmgate, Dhaka, Bangladesh \\ ${ }^{2}$ School of Environment, Resources and Development, Asian Institute of Technology, \\ Bangkok, Thailand \\ ${ }^{3}$ Ministry of Agriculture, Bangladesh Secretariat, Dhaka-1000, Bangladesh
}

\begin{abstract}
A pot experiment was carried out to evaluate the concentration and distribution of Lead, Cadmium and Nickel in industrial sludge. The test crop was Red Amaranth (Amaranthus gangeticus L.). Nitrogen was applied comprising the five combinations of different proportion of urea and industrial sludge and a control. Red Amaranth was harvested at 30 and 42 Days after sowing (DAS). Different physical and chemical analysis of soil, sludge, root, stem and leaf of the plant were carried out as required. Heavy metals concentration indicated the trends of $\mathrm{Pb}>\mathrm{Ni}>\mathrm{Cd}$ and distribution pattern of $\mathrm{Pb}, \mathrm{Cd}$ and $\mathrm{Ni}$ were identified Leaf $>$ root $>$ stem, Root $>$ leaf $>$ stem and Root> leaf $>$ stem respectively, both at 30 and 42 DAS with little exception. Industrial sludge had a significant influence on heavy metal concentration and distribution and contaminant food chain, although the data were below the maximum acceptable level.
\end{abstract}

Key Words: Industrial sludge, Concentration, Distribution pattern, Lead, Cadmium, Nickel, Red Amaranth

\section{Introduction}

In recent time environmental pollution is a global problem and a great threat to the existence of living world, the pollution being continuously aggravated. Heavy metals in sludge and soil are generally present in a variety of forms exhibiting different degrees of bioavailability and mobility (Salim et al. 1996). The corollary to the studies on the form of metals in sewage is that the metals coming from raw sludge determine their presence in the first instance. It is known that metals may be present as inorganic forms such as oxides, hydroxides, sulfides (Mosey et al. 1971) or as loose organic complex such as with humic acid or polysaccharides (Holtzclaw et al. 1970). Most system of controlling sludge application to the land involve the use of total metal concentration in sludge but in developing criteria to evaluate metals in sludge is essential to understand the nature of fraction present in the soil (Matthews 1984). Stover et al. (1976) has examined metal fractions in digested sludge by using a sequential extraction procedure for the separation of metals. Nevertheless, the procedure used by Stover et al. (1976) to rank the different forms of metal in digested sludge is as follows: Lead, carbonates>organic- bond>sulfides 
$>$ adsorbed $>$ exchangeable; $\mathrm{Cd}$,carbonates $>$ sulfides $>$ organic-ond $>$ adsorbed=exchangeable; $\mathrm{Ni}$, carbonates $>$ organic-bond $>$ exchangeable $>$ adsorbed $>$ sulfide .

Heavy metals such as zinc, copper, cadmium, chromium, nickel, mercury and lead can be phytotoxic. They accumulate in aquatic and terrestrial habitats and simultaneously contaminate the animal and human food chains, and hence will also cause diseases in human (Chaney 1983). Plants take up high level of nickel easily which cause toxicity to plants. However, $\mathrm{Ni}$ is an essential micronutrient to plant which is required by urease enzyme to hydrolyze urea formed in plants and avoid $\mathrm{NH}_{3}$ toxicity (Salisbury and Ross 1992). Lead is also micronutrient in plant, but can cause damage to central and peripheral nervous systems, kidney and highly toxic to infants and pregnant women. Lead, $\mathrm{Cd}, \mathrm{Ni}$ etc. in fertilizers and pesticides are important factors causing pollution. In contrast to most pollutants, these are not biodegradable. The result of pollutants undergoing global ecological cycles causes severe environmental pollution.

Many vegetables are grown in Bangladesh. Red Amaranth is one of them and grown in wide range in the country including industrial effluent contaminated lands too. Farmers use industrial sludge as a nutrient supplement without knowing its nutrient or toxic metal concentration. The crop may contain toxic or heavy metals from the effluent and sludge, which may be harmful to food chain. So, it is important to investigate the concentration and distribution pattern of heavy metals by the different parts of plant collected from sludge and effluent. The information could be helpful for developing techniques to handle such types of wastes and people would be concern about use of waste (sludge/effluent) for the crops and vegetables production. The main objectives of the study was to determine the concentration and distribution pattern of selected heavy metals in different parts of red amaranth, so as to assess the safety and feasibility of consuming red amaranth grown in area contaminated with industrial sludge.

\section{Materials and Methods}

The experiment was carried out in pot in a net house of the Bangladesh Agricultural Research Institute (BARI), Joydebpur, Gazipur, Bangladesh. The experimental site was located at latitude $24^{\circ} 05^{\prime} \mathrm{N}$, longitude $90^{\circ} 16^{\prime} \mathrm{E}$ and altitude $8.4 \mathrm{~m}$ AMSL. Soil was silty clay loam belonging to Chiaata series in the Bangladesh soil classification system (Brammer and Saheed 1984). Industrial sludge was collected from 'Islam dyeing' and 'Dundy dyeing' industry at Konabari, Gazipur and Badsha, Niki and Combined dyeing industry at Katchpur, Narayanganj. The test crop was Red Amaranth (Amaranthus gangeticus L.), variety "BARI Lalshak-1". The experiments were designed to provide nutrient and heavy metals to red amaranth using different ratios of urea and industrial sludge. Six treatment combinations were prepared as $\mathrm{T} 1 . \mathrm{UN}_{100}+\mathrm{SN}_{0}(100 \%$ urea-N $+0 \%$ sludge-N), T2. $\mathrm{UN}_{75}+\mathrm{SN}_{25}\left(75 \%\right.$ urea-N $+25 \%$ sludge-N), T3. $\mathrm{UN}_{50}+\mathrm{SN}_{50}(50 \%$ urea$\mathrm{N}+50 \%$ sludge-N), T4. $\mathrm{UN}_{25}+\mathrm{SN}_{75}\left(25 \%\right.$ urea-N $+75 \%$ sludge-N), T5. $\mathrm{UN}_{0}+\mathrm{SN}_{100}$ $(0 \%$ urea- $\mathrm{N}+100 \%$ sludge- $\mathrm{N})$ and $\mathrm{T} 6$. Control $(0 \%$ urea- $\mathrm{N}+0 \%$ sludge- $\mathrm{N})$. The 
experiment was conducted in completely randomized design (CRD) with four replications. Phosphorous $(\mathrm{P})$ and potassium $(\mathrm{K})$ were applied at the rate of 40 and 112.5 $\mathrm{kg} / \mathrm{ha}$, respectively as per fertilizer recommendation guide-2005. Accordingly, each pot (5.0 kg of oven dry soil) was given approximately $0.09 \mathrm{~g} \mathrm{P}$ and $0.25 \mathrm{~g} \mathrm{~K}$ using triple super phosphate $(19.78 \% \mathrm{P})$ and muriate of potash $(50 \% \mathrm{~K})$. Nitrogen was applied at the rate of $250 \mathrm{~kg} / \mathrm{ha}$ and each pot received $0.6 \mathrm{~g}$ of $\mathrm{N}$ in the combinations of urea and sludge, depending upon the treatments.

Soil samples were collected initially, intermittently and after harvesting the crop. Three soil columns were collected from each pot using a core sampler to the depth of $20 \mathrm{~cm}$. These samples were then mixed to make a composite sample, air-dried, ground, sieved and stored in labeled polythene bags for laboratory analysis. Plant height was measured at 30 and 42 DAS, i.e. just prior to harvesting, in which the height of every plant in each pot from the soil level up to the apical bud was measured and average plant height was calculated and recorded. The plants were then uprooted (when soil was moist), properly washed and leaves, stems and roots were separated. Both fresh and oven dry weights were recorded after drying in an oven for 72 hours at $70{ }^{0} \mathrm{C}$. These samples were separately ground, labelled and stored for laboratory analysis.

The Particle-size analysis of the soil was made by combination of sieving and hydrometer method as described by Day (1965) and textural classes were determined by Marshall's Triangular Coordinate curve. In both soil and industrial sludge samples, pH was determined with distilled water (1:2.5) by Metrohm 691 digital pH meter (Jackson 1973). Organic carbon was determined using the dry combustion method, for which the LECO Model C 200 analyzer was used. The organic matter concentrations in samples were computed by multiplying the organic carbon concentration with 1.72 (Nelson and Sommers 1982). Total N was estimated by Micro-kjeldhal method (Jackson 1973).

Later, soil and industrial sludge extracts were prepared by ammonium acetate extraction method for determination of available K, DTPA extraction method for available $\mathrm{Zn}, \mathrm{Pb}$, $\mathrm{Cd}$ and $\mathrm{Ni}$ and Olsen method for available P (Jackson 1973). Plant extracts were prepared, by nitric $\left(\mathrm{HNO}_{3}\right)$ acid $(68 \%)$ digestion method using a specified weight of ground materials for computing total amount of selected elements including $\mathrm{Pb}, \mathrm{Cd}$ and $\mathrm{Ni}$. From the above soil, industrial sludge and plant extracts, $\mathrm{P}$ was determined colorimetrically (using spectrophotometer UV-Model lamda 11), K flame emission spectrophotometrically (using flame photometer Model Jenway pfp-7), $\mathrm{Pb}, \mathrm{Cd}, \mathrm{Ni}$ and $\mathrm{Zn}$ Atomic Absorption Spectrophotometrically.

\section{Results and Discussion}

The physical and chemical parameters of soil are tested and shown in Table1. The test results confirm that the soil did not have traceable levels of $\mathrm{Pb}, \mathrm{Cd}$ and $\mathrm{Ni}$. The total $\mathrm{N}$, labile $\mathrm{P}$ and $\mathrm{Zn}$ were at low levels; $\mathrm{K}$ and organic matter concentrations were at medium 
levels while $\mathrm{S}$ was at high level. The $\mathrm{pH}$ was 6.7 , which indicates that the soil was slightly acidic to neutral.

Table 1. Selected parameters of background soil used in the experimental pot.

\begin{tabular}{l|cc}
\hline Parameters & background soil $^{1 /}$ & Interpretation of Soil test values $^{2 /}$ \\
\hline Texture & Silty clay loam & - \\
$\mathrm{pH}$ & $6.7 \pm 0.091$ & Slightly alkaline to neutral \\
Moisture Concentration (\%) & $20.6 \pm 0.072$ & - \\
Organic C (\%) & $1.81 \pm 0.063$ & Medium class \\
Total N (\%) & $0.11 \pm 0.010$ & Low \\
Labile P (ppm) & $10.1 \pm 0.082$ & Low \\
Available K (meq/100g soil) & $0.17 \pm 0.011$ & Medium \\
Available S (ppm) & $28.9 \pm 1.04$ & Optimum \\
Available Zn (ppm) & $0.8 \pm 0.032$ & Low \\
Available Pb (ppm) & $1.05 \pm 0.012$ & Below max. Accept. level \\
Available Cd (ppm) & $0.06 \pm 0.032$ & Below max. Accept. level \\
Available Ni (ppm) & $0.46 \pm 0.042$ & - \\
\hline
\end{tabular}

${ }^{1 /}$ Soil used for the experiment. ${ }^{2 /}$ Source: Anon, 2005.

The physical and chemical parameters of industrial sludge are shown in Table 2 . Industrial sludge contained optimum, high and very high levels of $\mathrm{K}$, Organic carbon and $\mathrm{Zn}$, respectively. Labile $\mathrm{P}$ concentration was very low. Total $\mathrm{N}$ and $\mathrm{S}$ were considered to be available at moderate concentrations.

Table 2. Selected parameters of industrial sludge used in the experimental pot.

\begin{tabular}{l|r|c}
\hline Parameters & Industrial sludge & $\begin{array}{l}\text { Interpretation of Sludge test } \\
\text { values }^{2 /}\end{array}$ \\
\hline pH & $7.8 \pm 0.08$ & Slightly alkaline \\
Moisture Concentration (\%) & $28.8 \pm 0.08$ & - \\
Organic C (\%) & $2.6 \pm 0.08$ & High class \\
Total N (\%) & $0.2 \pm 0.02$ & Medium \\
Labile P (ppm) & $14.5 \pm 0.09$ & Low \\
Available K (meq/100g soil) & $0.36 \pm 0.01$ & Optimum \\
Available S (ppm) & $19.9 \pm 0.92$ & Medium \\
Available $\mathrm{Zn}(\mathrm{ppm})$ & $47.0 \pm 1.28$ & Very high \\
Available $\mathrm{Pb}(\mathrm{ppm})$ & $3.9 \pm 0.01$ & Below max. Accept. level \\
Available Cd (ppm) & $0.2 \pm 0.03$ & Below max. Accept. level \\
Available Ni (ppm) & $1.2 \pm 0.04$ & - \\
\hline
\end{tabular}

${ }^{1 /}$ Industrial sludge used as a proportion of treatment in exp. ${ }^{2 /}$ Source: Anon, 2005. 


\section{Lead concentration and distribution}

Root: The highest $\mathrm{Pb}$ concentration $\left(3.36 \mathrm{mgkg}^{-1}\right)$ in root was recorded in $\mathrm{T}_{4}$ receiving $75 \% \mathrm{~N}$ from industrial sludge and $25 \% \mathrm{~N}$ from urea at $30 \mathrm{DAS}$ (Table 3). The effect of this treatment was statistically similar to $T_{5}$ but superior to $T_{1}, T_{2}, T_{3}$ and $T_{6}$. The lowest $\mathrm{Pb}$ concentration $\left(1.92 \mathrm{mgkg}^{-1}\right)$ in root was observed in $\mathrm{T}_{6}$ (control). Highest $\mathrm{Pb}$ concentration $\left(3.30 \mathrm{mgkg}^{-1}\right)$ in root was recorded in $42 \mathrm{DAS}$ (Treatment $\mathrm{T}_{4}$ ). Lead concentration found in treatment $\mathrm{T}_{5}$ rank second in position. Treatment $\mathrm{T}_{2}$ and $\mathrm{T}_{3}$ identical to each other, rank third in position and superior to control.

Stem: The highest $\mathrm{Pb}$ concentration $\left(2.73 \mathrm{mgkg}^{-1}\right)$ in stem was recorded in $\mathrm{T}_{5}$ receiving $100 \% \mathrm{~N}$ from industrial sludge and $0 \% \mathrm{~N}$ from urea at 30 DAS (Table 3). Lead concentration found in treatment $T_{4}$ rank second in position which was followed by $T_{3}$. Treatment $T_{1}$ and $T_{2}$ were identical to each other and superior to control $\left(1.91 \mathrm{mgkg}^{-1}\right)$. The highest $\mathrm{Pb}$ concentration $\left(2.47 \mathrm{mgkg}^{-1}\right)$ was also recorded in stem at 42 DAS (Treatment $\mathrm{T}_{5}$ ). Lead concentration found in treatment $\mathrm{T}_{4}$ rank second in position and the effect of this treatment was identical to $\mathrm{T}_{2}$ and $\mathrm{T}_{3}$, but superior to control. The lowest $\mathrm{Pb}$ concentration $\left(1.32 \mathrm{mgkg}^{-1}\right)$ in stem was observed in $\mathrm{T}_{6}$ (control).

Leaf: Similar to stem the highest $\mathrm{Pb}$ concentration $\left(3.99 \mathrm{mgkg}^{-1}\right)$ in leaf was noted in $\mathrm{T}_{5}$ at 30 DAS (Table 3). The rank of treatment $\mathrm{T}_{4}$ was second in position and that was identical to $T_{2}$ and $T_{3}$ but superior to $T_{1}$ and $T_{6}$ like as 30 DAS. Treatment $T_{5}$ showed highest $\mathrm{Pb}$ concentration $\left(3.36 \mathrm{mgkg}^{-1}\right)$ in leaf at 42 DAS. In treatment $\mathrm{T}_{1}$ and $\mathrm{T}_{2}$ recorded $\mathrm{Pb}$ concentration was statistically similar and inferior from $T_{3}$ and $T_{4}$, but superior to $T_{6}$. The lowest $\mathrm{Pb}$ concentration was identified in control $\left(1.89 \mathrm{mgkg}^{-1}\right)$. Increasing sludge concentration in the treatment showed higher $\mathrm{Pb}$ concentration in root, stem and leaf of red amaranth.

Table 3. Lead concentration in root, stem and leaf of red amaranth as influenced by urea and sludge-N at 30 and 42 DAS.

\begin{tabular}{|c|c|c|c|c|c|c|}
\hline \multirow[t]{3}{*}{ Treatment } & \multicolumn{6}{|c|}{$\mathrm{Pb}\left(\mathrm{mgkg}^{-1}\right.$ dry matter) } \\
\hline & \multicolumn{2}{|c|}{ Root } & \multicolumn{2}{|c|}{ Stem } & \multicolumn{2}{|c|}{ Leaf } \\
\hline & $30 \mathrm{DAS}^{1 /}$ & 42 DAS & 30 DAS & 42 DAS & $30 \mathrm{DAS}$ & 42 DAS \\
\hline T1. $\mathrm{UN}_{100}+\mathrm{SN}_{0}$ & $2.55 \mathrm{~d}$ & $2.57 \mathrm{~d}$ & $2.00 \mathrm{~d}$ & $1.36 \mathrm{c}$ & $2.69 \mathrm{c}$ & $2.66 \mathrm{~d}$ \\
\hline T2. $\mathrm{UN}_{75}+\mathrm{SN}_{25}$ & $2.70 \mathrm{c}$ & $2.65 \mathrm{c}$ & $2.04 d$ & $2.00 \mathrm{~b}$ & $3.37 \mathrm{~b}$ & $2.69 \mathrm{~d}$ \\
\hline T3. $\mathrm{UN}_{50}+\mathrm{SN}_{50}$ & $2.99 b$ & $2.69 \mathrm{c}$ & $2.21 \mathrm{c}$ & $2.09 \mathrm{~b}$ & $3.33 b$ & $2.76 \mathrm{c}$ \\
\hline T4. $\mathrm{UN}_{25}+\mathrm{SN}_{75}$ & $3.36 \mathrm{a}$ & $3.30 \mathrm{a}$ & $2.59 \mathrm{~b}$ & $2.21 \mathrm{~b}$ & $3.47 \mathrm{~b}$ & $3.31 \mathrm{~b}$ \\
\hline T5. $\mathrm{UN}_{0}+\mathrm{SN}_{100}$ & $3.32 \mathrm{a}$ & $2.98 b$ & $2.73 \mathrm{a}$ & $2.47 \mathrm{a}$ & $3.99 \mathrm{a}$ & $3.36 \mathrm{a}$ \\
\hline T6. Control & $1.92 \mathrm{e}$ & $1.94 \mathrm{e}$ & $1.91 \mathrm{e}$ & $1.32 \mathrm{c}$ & $1.96 \mathrm{e}$ & $1.89 \mathrm{e}$ \\
\hline $\operatorname{LSD}(\mathrm{P}=0.05)$ & 0.067 & 0.057 & 0.055 & 0.22 & 0.19 & 0.033 \\
\hline $\mathrm{CV} \%$ & 1.54 & 1.37 & 1.63 & 7.54 & 3.81 & 0.78 \\
\hline
\end{tabular}

$\mathrm{U}_{\mathrm{N}}-$ Nitrogen from urea; $\mathrm{S}_{\mathrm{N}}-$ Nitrogen from industrial sludge; 1/ DAS - Days after seeding; Means followed by common letter (s) in a column are not significantly different at $5 \%$ level by DMRT. 


\section{Cadmium concentration and distribution}

Root: The highest amount of $\mathrm{Cd}\left(0.04 \mathrm{mgkg}^{-1}\right)$ was recorded in $\mathrm{T}_{5}$ in root at $30 \mathrm{DAS}$ (Table 4). The effect of this treatment was statistically similar to $T_{2}, T_{3}$ and $T_{4}$, but superior to $\mathrm{T}_{1}$, and $\mathrm{T}_{6}$. The lowest Cd concentration $\left(0.01 \mathrm{mgkg}^{-1}\right)$ in root was observed in $\mathrm{T}_{6}$ (control). The highest Cd concentration $\left(2.06 \mathrm{mgkg}^{-1}\right)$ was recorded in $\mathrm{T}_{4}$ in root at 42 DAS. Cadmium concentration found in treatment $\mathrm{T}_{5}$ rank second in position. Treatment $\mathrm{T}_{2}$ and $\mathrm{T}_{3}$ were identical to each other and rank third in position and superior to control.

Stem: Treatment $\mathrm{T}_{5}$ recoded the highest Cd concentration $\left(0.02 \mathrm{mgkg}^{-1}\right)$ in stem at 30DAS (Table 4). The effect of this treatment was statistically similar to $\mathrm{T}_{3}$, and $\mathrm{T}_{4}$, but superior to $\mathrm{T}_{1}, \mathrm{~T}_{2}$ and $\mathrm{T}_{6}$. The lowest $\mathrm{Cd}$ concentration $\left(0.01 \mathrm{mgkg}^{-1}\right)$ in stem was observed in $\mathrm{T}_{6}$ (control). The highest $\mathrm{Cd}$ concentration $\left(1.85 \mathrm{mgkg}^{-1}\right)$ in leaf was recorded in $\mathrm{T}_{5}$ at 42 DAS. The rank of treatment $T_{4}$ was second in position and that was identical to $T_{2}$ and $T_{3}$, but superior to $\mathrm{T}_{1}$ and $\mathrm{T}_{6}$.

Leaf: The highest $\mathrm{Cd}$ concentration $\left(0.03 \mathrm{mgkg}^{-1}\right)$ in leaf was recorded in $\mathrm{T}_{5}$ at $30 \mathrm{DAS}$ (Table 4). The effect of this treatment was statistically similar to $\mathrm{T}_{4}$, but superior to rest of the treatments. Treatment $\mathrm{T}_{1}, \mathrm{~T}_{2}$, and $\mathrm{T}_{6}$ were identical in respect of $\mathrm{Cd}$ concentration. The lowest $\mathrm{Cd}$ concentration $\left(0.01 \mathrm{mgkg}^{-1}\right)$ in leaf was observed in $\mathrm{T}_{6}$ (control). The highest $\mathrm{Cd}$ concentration $\left(1.84 \mathrm{mgkg}^{-1}\right)$ was recorded in $\mathrm{T}_{4}$ at 42 DAS that was statistically similar to $T_{5}$ but superior to $T_{1}, T_{2}, T_{3}$ and $T_{6}$. It was found that cadmium concentration was higher at 42 DAS compared to 30 DAS in all plant parts and higher values were in roots. Higher $\mathrm{Cd}$ concentration was also found in the treatment where $\mathrm{N}$ was given by $100 \%$ sludge only.

Table 4. Cadmium concentration in root, stem and leaf of red amaranth as influenced by urea and sludge- $\mathrm{N}$ at 30 and 42 DAS.

\begin{tabular}{|c|c|c|c|c|c|c|}
\hline \multirow[t]{3}{*}{ Treatment } & \multicolumn{6}{|c|}{$\mathrm{Cd}^{\left(\mathrm{mgkg}^{-1} \text { dry matter}\right)}$} \\
\hline & \multicolumn{2}{|c|}{ Root } & \multicolumn{2}{|c|}{ Stem } & \multicolumn{2}{|c|}{ Leaf } \\
\hline & $30 \mathrm{DAS}^{1 /}$ & 42 DAS & 30 DAS & 42 DAS & $30 \mathrm{DAS}$ & 42 DAS \\
\hline T1. $\mathrm{UN}_{100}+\mathrm{SN}_{0}$ & $0.01 b$ & $1.70 \mathrm{~cd}$ & $0.01 b$ & $1.06 \mathrm{c}$ & $0.01 \mathrm{c}$ & $1.08 \mathrm{~d}$ \\
\hline T2. $\mathrm{UN}_{75}+\mathrm{SN}_{25}$ & $0.02 \mathrm{ab}$ & $1.84 \mathrm{bc}$ & $0.01 b$ & $1.27 \mathrm{~b}$ & $0.01 \mathrm{c}$ & $1.28 \mathrm{c}$ \\
\hline T3. $\mathrm{UN}_{50}+\mathrm{SN}_{50}$ & $0.03 \mathrm{ab}$ & $1.88 \mathrm{~b}$ & $0.02 \mathrm{ab}$ & $1.21 \mathrm{~b}$ & $0.02 b$ & $1.54 \mathrm{~b}$ \\
\hline T4. $\mathrm{UN}_{25}+\mathrm{SN}_{75}$ & $0.04 \mathrm{a}$ & $2.06 \mathrm{a}$ & $0.02 \mathrm{ab}$ & $1.30 \mathrm{~b}$ & $0.02 \mathrm{ab}$ & $1.84 \mathrm{a}$ \\
\hline T5. $\mathrm{UN}_{0}+\mathrm{SN}_{100}$ & $0.04 \mathrm{a}$ & $1.94 \mathrm{ab}$ & $0.02 \mathrm{a}$ & $1.85 \mathrm{a}$ & $0.03 \mathrm{a}$ & $1.82 \mathrm{a}$ \\
\hline T6. Control & $0.01 \mathrm{~b}$ & $1.61 d$ & $0.01 b$ & $0.05 \mathrm{~d}$ & $0.01 \mathrm{c}$ & $0.76 \mathrm{e}$ \\
\hline $\operatorname{LSD}(\mathrm{P}=0.05)$ & 0.176 & 0.176 & 0.0063 & 0.136 & 0.005 & 0.164 \\
\hline $\mathrm{CV} \%$ & 6.29 & 6.37 & 3.04 & 9.44 & 21.05 & 7.86 \\
\hline
\end{tabular}

$\mathrm{U}_{\mathrm{N}}$ - Nitrogen from urea; $\mathrm{S}_{\mathrm{N}}-$ Nitrogen from industrial sludge; 1/ DAS - Days after seeding; Means followed by common letter (s) in a column are not significantly different at $5 \%$ level by DMRT. 


\section{Nickel concentration and distribution}

Root: The highest Ni concentration $\left(0.53 \mathrm{mgkg}^{-1}\right)$ in root at $30 \mathrm{DAS}$ (Table 5) was recorded in $T_{5}$. Treatment $T_{3}$ was second in position and that was identical to $T_{1}, T_{2}$ and $\mathrm{T}_{4}$ but superior to $\mathrm{T}_{6}$. The lowest $\mathrm{Ni}$ concentration $\left(0.26 \mathrm{mgkg}^{-1}\right)$ in root was observed in $\mathrm{T}_{6}$. The highest $\mathrm{Ni}$ concentration $\left(2.48 \mathrm{mgkg}^{-1}\right)$ in root was recorded in $\mathrm{T}_{5}$ at $42 \mathrm{DAS}$ (Table 5). Treatment $\mathrm{T}_{4}$ was second in position and that was statistically similar to $\mathrm{T}_{3}$ but superior to $\mathrm{T}_{1}, \mathrm{~T}_{2}$ and $\mathrm{T}_{6}$.

Stem: The highest Ni concentration $\left(0.42 \mathrm{mgkg}^{-1}\right)$ in root was noted in $\mathrm{T}_{5}$ at $30 \mathrm{DAS}$ (Table 5). Treatment $\mathrm{T}_{4}$ rank second in position and that was identical to $\mathrm{T}_{3}$ but superior to $\mathrm{T}_{1} \mathrm{~T}_{2}$ and $\mathrm{T}_{6}$. The highest $\mathrm{Ni}$ concentration $\left(1.72 \mathrm{mgkg}^{-1}\right)$ in stem was recorded in $\mathrm{T}_{5}$ at 42 DAS (Table 5). Treatment $\mathrm{T}_{4}$ was second in position and that was statistically similar to $\mathrm{T}_{2}$ and $\mathrm{T}_{3}$, but superior to $\mathrm{T}_{1}$ and $\mathrm{T}_{6}$.

Leaf: The highest $\mathrm{Ni}$ concentration $\left(0.56 \mathrm{mgkg}^{-1}\right)$ in leaf was recorded in $\mathrm{T}_{5}$ at $30 \mathrm{DAS}$ (Table 5). Treatment $\mathrm{T}_{4}$ was second in position and that was statistically similar to $\mathrm{T}_{3}$, but superior to $\mathrm{T}_{1}, \mathrm{~T}_{2}$ and control. The lowest $\mathrm{Ni}$ concentration $\left(0.27 \mathrm{mgkg}^{-1}\right)$ in leaf was recorded in $\mathrm{T}_{6}$ at 30 DAS (Table 5). The highest Ni concentration $\left(2.12 \mathrm{mgkg}^{-1}\right)$ in leaf was observed in $T_{5}$ at 42 DAS. Treatment $T_{4}$ was second in position. Treatment $T_{2}$ rank third in position and statistically similar to $T_{3}$ but superior to $T_{1}$ and $T_{6}$. From above discussion, it is revealed that higher amount of Ni was found at 42 DAS compared to 30 DAS in all parts of plant and higher values were in roots. Nickel is considered as a micronutrient in plants (Salisbury and Ross 1982). This nutrient is considered in many plants to be essential in order to avoid urea toxicity by acting as a co-factor for the urease enzyme to hydrolyze urea formed.

Table 5. Nickel concentration in root, stem and leaf of red amaranth as influenced by urea and sludge- $\mathrm{N}$ at 30 and 42 DAS.

\begin{tabular}{|c|c|c|c|c|c|c|}
\hline \multirow[t]{3}{*}{ Treatment } & \multicolumn{6}{|c|}{$\mathrm{Ni}\left(\mathrm{mgkg}^{-1}\right.$ dry matter) } \\
\hline & \multicolumn{2}{|c|}{ Root } & \multicolumn{2}{|c|}{ Stem } & \multicolumn{2}{|c|}{ Leaf } \\
\hline & $30 \mathrm{DAS}^{1 /}$ & 42 DAS & $30 \mathrm{DAS}$ & 42 DAS & 30 DAS & 42 DAS \\
\hline T1. $\mathrm{UN}_{100}+\mathrm{SN}_{0}$ & $0.31 \mathrm{~b}$ & $2.06 \mathrm{~d}$ & $0.23 b c$ & $0.99 \mathrm{c}$ & $0.31 \mathrm{c}$ & $1.29 \mathrm{~d}$ \\
\hline T2. $\mathrm{UN}_{75}+\mathrm{SN}_{25}$ & $0.32 b$ & $2.16 \mathrm{c}$ & $0.24 b c$ & $1.02 \mathrm{bc}$ & $0.32 \mathrm{c}$ & $1.41 \mathrm{c}$ \\
\hline T3. $\mathrm{UN}_{50}+\mathrm{SN}_{50}$ & $0.34 b$ & $2.23 b$ & $0.25 b$ & $1.02 \mathrm{bc}$ & $0.33 \mathrm{bc}$ & $1.40 \mathrm{c}$ \\
\hline T4. $\mathrm{UN}_{25}+\mathrm{SN}_{75}$ & $0.32 b$ & $2.23 \mathrm{~b}$ & $0.26 \mathrm{~b}$ & $1.06 \mathrm{~b}$ & $0.35 b$ & $1.51 \mathrm{~b}$ \\
\hline T5. $\mathrm{UN}_{0}+\mathrm{SN}_{100}$ & $0.53 \mathrm{a}$ & $2.48 \mathrm{a}$ & $0.42 \mathrm{a}$ & $1.72 \mathrm{a}$ & $0.56 \mathrm{a}$ & $2.12 \mathrm{a}$ \\
\hline T6. Control & $0.26 \mathrm{c}$ & $1.96 \mathrm{e}$ & $0.21 \mathrm{c}$ & $0.96 \mathrm{c}$ & $0.27 \mathrm{~d}$ & $1.10 \mathrm{e}$ \\
\hline $\operatorname{LSD}(\mathrm{P}=0.05)$ & 0.032 & 0.058 & 0.031 & 0.062 & 0.03 & 0.074 \\
\hline CV\% & 6.16 & 1.77 & 7.64 & 3.66 & 5.6 & 3.36 \\
\hline
\end{tabular}

$\mathrm{U}_{\mathrm{N}}$ - Nitrogen from urea; $\mathrm{S}_{\mathrm{N}}-$ Nitrogen from industrial sludge; 1/ DAS - Days after seeding; Means followed by common letter (s) in a column are not significantly different at $5 \%$ level by DMRT. 


\section{Acknowledgements}

The senior authors are grateful to the Asian Institute of Technology, Bangkok, Thailand and Chief Technical advisor, DANIDA, Royal Danish Embassy, Dhaka for their assistance in conducting the experiment.

\section{References}

Anon. 2005. Fertilizer recommendation guides. Bangladesh Agricultural Research Council, Farmgate, Airport road, Dhaka 1215, Bangladesh. 120 p.

Brammer, H. and S.M. Saheed. 1984. Soil Resources. Soil Survey Project Bangladesh. AGL. Sf/ Pak. 6. Technical Report No. 3, FAO- UNDP, Rome, Italy FAO- UNDP 1988 Land Resources Appraisal of Bangladesh for Agricultural Development. Report No. 2, Agroecological Regions of Bangladesh. BGD/81/035, Technical Report No. 2. Rome, Italy. 66-70 pp.

Chaney. 1983. Transfer of Sludge Applied Trace Elements to the Food Chain, In Page AL et al. (eds.). Land Application of Sludge, Lewis Publishers, Chelsea, MI. pp 67-99.

Day, P. R. 1965. Particle formation and particle- size analysis. In: Methods of Soil analysis C. A. Black, D.D. Evans, J. L. White, L. E. Enswinger and F. E. Clark (eds). Agronomy Monograph, part I. Academic Press, New York. 545-567 pp.

Jackson, M. L. 1973. Soil Chemical Analysis. Prentice Hall of India (Pvt.). Ltd. New Delhi.

Holtzclaw, K. M., D. A., Keech, A. L. Page, G. T. J. Sposito, Ganje and N. B. Ball, 1970. Trace Metal Ddistributions among Humic acid, Fulvic acid and Precipatable Fractions Extracted with $\mathrm{NaOH}$ from Sewage Sludge., J. Environ. Qual., 7:124.

Matthews, P.J., 1984. Control of Metal Application Rates from Sewage Sludge Utilization in Agriculture. Crit. Rev. In Env. Cont., (14:3)199-250. pp

Mosey, F. E., J. D. Swanwick and D. A. Havghes. 1971. Factors Affecting the availability of Heavy Metals to Inhibit Anaerobic Digestion., Water Pollut. Control 70: 688. pp.

Nelson, D. W., L.E. Sommers 1982. Total Carbon, Organic Carbon, and Organic matter.

A.L. Page, R.H. Miller, and D.R. Keenley (eds.) Methods of soil analysis, part 2, Agron.I. Am. Soc. Agron., Madison, Wisconsin 539-579 pp.

Salisbury, F. B. and C.W. Ross. 1992. Mineral nutrition, Chapter-3 in plant Physiology, Third Edition, Wadsworth Inc., Belmont, California, USA. 77. pp.

Salim, Imad A., J. Miller, Carol and Howard, L. Jeffrey, 1996. Sorption Isotherm-Sequential Extraction Analysis of Heavy Metal Retention in landfill Liners, Soil Sci. Soc. Am. J. (60):107- 114.

Stover R.C., L.E. Sommers and Silviera, 1976. Evaluation of Metals in Wastewater Sludge, J. Water Pollut. Control Fed. 48: 2165-2175. 